\title{
Contraceptive Method Preferences of Women and Related Factors in Karabuk Province
}

\section{Karabük İlinde Kadınların Kontraseptif Yöntem Tercihleri ve İlişkili Faktörler}

\author{
Semra Eroğlü, Vusale Aziz², Fatma Kılıç ${ }^{* 3}$
}

\begin{abstract}
Aim: The aim of this study was to investigate the contraceptive choices of women in Karabuk between the ages of 15-49 and explore the factors affecting the contraceptive method preferences. Methods: A total of 2018 women who applied to Family Planning Polyclinic between January 2016 and 2018 were included in this study. Patients' age, place of residence, education status, marital status, obstetric history, and family planning preferences were recorded. While evaluating the study data, percentage, average, and Chi-square test were used and $\mathrm{p}<0.05$ was considered as the value of significance. Results: The mean age of the study group was $32.31 \pm 7.78(15-49)$ years. $84.5 \%$ of the participants used contraceptive methods and $27.6 \%$ of them were traditional and $56.9 \%$ were modern methods. The most used method was Intrauterine devices (IUD) with $32.2 \%$ and it was most preferred at the age of $\geq 25$. The most used method under the age of 25 was the withdrawal method with $27.6 \%(p=0.000)$. Conclusion: The most frequently used contraceptive method in our region is the IUD which long-acting reversible method. Family planning is an important health service offered in all health institutions, especially in the primary health care centers for the prevention of unwanted pregnancies.
\end{abstract}

Key Words: Fertility control, Contraceptive choices, Contraception, Intrauterine devices

ÖZET

Amaç: Bu çalışmanın amacı Karabük'teki kadınların 15-49 yaş arasındaki doğum kontrol seçimlerini incelemek ve yöntem tercihlerini etkileyen faktörleri araştırmaktır. Yöntem: Ocak 2016-2018 tarihleri arasında Aile Planlaması polikliniğine başvuran toplam 2018 kadın çalışmaya dahil edildi. Hastaların yaşı, ikamet yeri, eğitim durumu, evlilik durumu, obstetrik öyküsü ve aile planlaması tercihleri kaydedildi. Çalışma verileri değerlendirilirken yüzde, ortalama ve Ki-kare testi kullanıldı ve $\mathrm{P}<0.05$ anlamlılık değeri olarak kabul edildi. Bulgular: Çalışma grubunun yaş ortalaması $32.31 \pm 7.78$ yıl idi. Katılımcıların \% 84,5'i kontraseptif yöntem kullanıyordu ve bunun \% 27,6'sı geleneksel, \% 56,9'u modern yöntemlerdi. En sık kullanılan yöntem \% 32.2 ile rahim içi araç (RİA) idi ve bu yöntem en çok $\geq 25$ yaş tercih ediliyordu. 25 yaş altında en sık kullanılan yöntem, $\% 27.6$ ile geri çekme yöntemiydi $(p=0.000)$. Sonuç: Bölgemizde en sık kullanılan kontraseptif yöntem, uzun etkili geri dönüșümlü bir yöntem olan RİA'dır. Aile planlaması, istenmeyen gebeliklerin önlenmesi için ülkemizde birinci basamak başta olmak üzere tüm sağlık kuruluşlarında sunulan önemli bir sağlık hizmetidir.

Anahtar Kelimeler: Doğurganlık Kontrolü, Kontraseptif tercihler, Kontrasepsiyon, Rahim içi araç

Received / Geliş tarihi: 28.02.2020, Accepted / Kabul tarihi: 06.12.2020

${ }^{1}$ Başkent Üniversitesi Konya Araştırma Ve Uygulama Merkezi Kadın Doğum Kliniği, Konya , TÜRKIYYE.

${ }^{2}$ Karabük Eğitim Araştırma Hastanesi Kadın Doğum Kliniği, Karabük, TÜRKIYYE.

${ }^{3}$ Necmettin Erbakan Üniversitesi Meram Tıp Fakültesi Kadın Doğum Kliniği, Konya, TÜRKIYE.

*Address for Correspondence / Yazışma Adresi: Fatma KILIÇ, Necmettin Erbakan Üniversitesi Meram Tıp Fakültesi Kadın Doğum Kliniği, Konya, TÜRKIYE.

E-mail: dr_fatmakilic_78@hotmail.com

Eroglu S, Aziz V, Kilic F. Contraceptive Method Preferences of Women and Related Factors in Karabuk Province. TJFMPC, 2021;15(1): 72-77.

DOI: $10.21763 /$ tjfmpc.744282 


\section{INTRODUCTION}

Family planning means the ability of individuals to have as many children as they want and when they want and to determine the size of their families. ${ }^{1}$ Besides the quality of health services, the main objective of family planning required for the continuity of population planning is to regulate general women's health, to improve maternal and fetal health levels, to inform people correctly, providing counseling to prevent unwanted pregnancy. ${ }^{1-3}$ With this objective, the priority is to ensure that women have a safe pregnancy. Giving birth at intervals of less than two years, being under the age of 18 and over 35 , giving birth four times and above causes physical and psychological exhaustion in the mother and an increase in maternal and infant mortality. ${ }^{6}$ In a study evaluating maternal deaths in the USA, the most common cause of maternal death was the ectopic pregnancy. Also, the age of pregnancy older than 30 years founded a risk factor for maternal death. ${ }^{4}$ Reducing the health problems associated with a high number of pregnancies and births can only be achieved by expanding the effective use of family planning methods. Family planning is an important health service in all health institutions, especially in primary health care centers. ${ }^{5}$

Contraception is a technique for preventing pregnancy after sexual intercourse. The methods used for this purpose are called contraceptive methods. Currently, the known contraceptive methods are grouped into two, modern and traditional. Traditional methods are withdrawal, lactational amenorrhea, vaginal douching, and menstrual follow-up (basal body temperature method, calendar method, cervical mucus method). Modern methods are defined as intrauterine device, oral contraceptives, barrier methods, injectable contraceptives (mesigyna, depo-provera), progesterone-only pills, implants (norplant, implanon) and sterilization methods (female or male sterilization). ${ }^{6,7}$

Studies on women's family planning method preferences have been conducted in reproductive health services in the world and the data was found to vary from region to region, urban and rural location, educational status of the patients, age and number of pregnancies and births., ${ }^{8,9}$ In our country, Turkey Demographic and Health Surveys (TDHS) offer data about family planning preferences for women at certain intervals. ${ }^{6}$ In the literature, the results of the studies on family planning method preferences in different regions of our country differ. ${ }^{10,12}$ The differences in studies may be due to differences in methodology and sample size. ${ }^{12}$ Thus, determining and evaluating the data in our region will be beneficial in terms of reproductive health and continuity of contraception. By choosing the most suitable method for women with correct information about family planning methods, our goals to ensure contraception continuity as well as reducing unwanted pregnancies and complications that these pregnancies may cause. Our aim in this study is to examine the contraceptive method preferences of women aged 15-49 years who presented at the Family Planning Polyclinic of Karabuk Training and Research Hospital and factors affecting them.

\section{PATIENTS AND METHOD}

Approval for this retrospective, cross-sectional study was granted by the Non-interventional Ethics Committee of Karabuk University (decision no: 6/27, dated: 07.10.2019). Karabuk is located in the Western Black Sea region of Turkey. Our tertiary hospital serves approximately 245,000 people and there are 1200 births per year. Women in the reproductive period between the ages of 15-49 who applied to the Family Planning Polyclinic of Karabuk Training and Research Hospital between January 2016 and January 2018 for check-ups or gynecological problems were enrolled in this study. The exclusion criteria were pregnant, had any genetic disease, anatomic disorder, endocrine disease, had used hormone therapy in the previous month, cancer, and chronic diseases (hypertension, diabetes mellitus, rheumatological disease).

The research data were obtained retrospectively from the information recorded on family planning forms by doctors and nurses at the time of application. Patients' age, place of residence, and education status, number of pregnancies, births, miscarriages, abortions, live children, stillbirths, and unwanted pregnancies were recorded. Sociodemographic data, obstetric data and family planning preferences of the women were compared according to their age groups, settlements, and educational status.

The sample size was determined based on the single population proportion formula with a seroprevalence value $(\mathrm{p}=58.8 \%)$ taken from a previous study from Turkey with a desired absolute precision of $5 \%$ and $95 \%$ CI (confidence intervals). ${ }^{10}$ For statistical analysis, Statistical Package for Social Sciences 23.0 (SPSS Inc. Chicago, IL) was used. When 
evaluating study data, frequencies, mean, standard deviation, median, minimum and maximum values; in comparison of qualitative data, Chi-square test was used and $\mathrm{p}<0.05$ was used as the level of significance.

\section{RESULTS}

The mean age of the patients in the study group was $32.31 \pm 7.78(15-49)$ years. Average gravida was 2 (1-12), parity was 2 (1-4), abortion was 0.47 (0-9) and the average number of living children was 2 (1-10). According to their educational status, $70.3 \%$ (1418) were primary education level. When analyzed by settlements, 62,7\% (1266) lived in the urban area, $37.3 \%$ (752) lived in the rural area. $99.8 \%$ of the participants were married.

\begin{tabular}{|c|c|c|}
\hline Variables & $\mathrm{N}(\mathrm{n}=2018)$ & $\%$ \\
\hline \multicolumn{3}{|l|}{ Settlement } \\
\hline Urban & 1266 & 62.7 \\
\hline Rural & 752 & 37.3 \\
\hline \multicolumn{3}{|l|}{ Age range } \\
\hline $15-19$ & 76 & 3.8 \\
\hline $20-24$ & 277 & 13.7 \\
\hline $25-29$ & 428 & 21.2 \\
\hline $30-34$ & 462 & 22.9 \\
\hline $35-39$ & 401 & 19.9 \\
\hline $40-44$ & 258 & 12.8 \\
\hline $45-50$ & 116 & 5.7 \\
\hline \multicolumn{3}{|l|}{ Educational status } \\
\hline No education & 21 & 1.0 \\
\hline Primary Education & 1418 & 70.3 \\
\hline High school & 421 & 20.9 \\
\hline University & 157 & 7.8 \\
\hline
\end{tabular}

Despite the contraceptive methods, $7.9 \%$ of the patients became pregnant and this resulted in elective termination. The contraceptive method most used by these patients was withdrawal methods. When the last form of delivery was examined, 53.1\% (1071) was normal delivery, $38.7 \%$ (780) cesarean section, $0.3 \%$ (7) abortion and $7.9 \%$ (159) elective termination. Table 1 shows the demographic findings of the women aged between 15-49 in the study groups.

While a total of $84.5 \%$ (1715) patients in the patient group that were included in the study used contraceptive methods, \%15.5'i (303) didn't use any contraceptive method. Among the contraceptive methods, $27.6 \%$ were traditional and $56.9 \%$ were modern methods. The most frequently used among all methods was intrauterine device (IUD) (32.2\%). Among the modern methods, the most used method was intrauterine devices (IUD) $32.2 \% \quad$ (649), condom in the second place with $13.9 \%$ (281), and oral contraceptive pill (OCP) in third place with $(7.8 \%)$. Injectable preparations and bilateral tubal ligation (BTL) were among other modern methods with $2.1 \%$ (42) and $1.0 \%$ (20) respectively. $27.6 \%$ (556) of patients used traditional method of withdrawal for prevention.

When women in the study group were separated according to their age groups, the most common method between the ages of 1524 was withdrawal $(30.9 \%)$, while there was no patient who preferred BTL. The most commonly used method in the 25-34 age group was IUD $(28.2 \%)$ followed by withdrawal $(27.6 \%)$, and the least used was injectable preparations $(2.8 \%)$. In the $35-44$ age range, the most common method was IUD (37.8\%) followed by withdrawal $(28.7 \%)$ and the least was injectable preparations (1.1\%). While BTL was not preferred at the ages of 15-24, it was highly preferred for the women over 35 years of age. IUD use was used at a higher rate over the age of 25 compared to below the age of 25 ( $p=$ 0.000) (Table 2). 


\begin{tabular}{|}
\hline Table 2. The relationship between the age groups of women and the use of contraceptive methods \\
\hline \multirow{3}{*}{$\begin{array}{l}\text { Contraceptive } \\
\text { Methods }\end{array}$} & \multicolumn{5}{|c|}{ Age groups } & \\
\cline { 2 - 6 } & $\mathrm{N}(\%)$ & $15-24$ years & $25-34$ years & $\geq 35$ years & \multirow{2}{*}{ p value } \\
\cline { 2 - 5 } & & $\mathrm{N}=398(\%)$ & $\mathrm{N}=937(\%)$ & $\mathrm{N}=683(\%)$ & \\
\hline No method & $313(15.5)$ & $94(25.2)$ & $131(14.7)$ & $88(12.6)$ & \\
\hline Oral contraceptive pill & $157(7.8)$ & $25(6.8)$ & $82(9.2)$ & $50(7.6)$ & \\
\hline Intrauterine device & $645(32.2)$ & $96(19.3)$ & $290(32.4)$ & $259(37.8)$ & \multirow{2}{*}{0.000} \\
\hline Condom & $275(13.9)$ & $61(15.6)$ & $147(16.5)$ & $73(11.1)$ & \\
\hline Tubal ligation & $20(1.0)$ & $0(0)$ & $8(0.9)$ & $12(1.2)$ & \\
\hline Injectable preparations & $42(2.1)$ & $8(2.3)$ & $25(2.8)$ & $7(1.1)$ & \\
\hline Withdrawal method & $565(27.6)$ & $114(30.9)$ & $251(27.6)$ & $194(28.7)$ & \\
\hline
\end{tabular}

Chi-square test, $\mathrm{p}<0.05$ statistically significant.

When the educational status of women in the study group was examined, the IUD was the most frequently used method among all groups, followed by the withdrawal method. As the education level increased, the usage of condomrate was increasing but there is no significant difference between educational

\section{DISCUSSION}

Family planning method preferences change according to the age, education, marital status, place of residence, religious beliefs, and cultural values of the person. In addition, the selection of the methods that have been used also differs at the individual level.. Selection of unsuitable methods for women may lead to unwanted pregnancy and negative effects on public health. ${ }^{6}$ Therefore, accessibility and awareness of family planning methods are important for every country.

In Karabuk, the rate of using any family planning method is $84.5 \%, 27.6 \%$ of these are traditional and $56.9 \%$ are modern methods. According to TDHS 2013's data, contraception usage rates across the country $\% 73.4$, and modern methods usage rates $47.4 \%$ in Turkey, $46 \%$ in the western black sea region, respectively. ${ }^{6}$ According to TDHS 2018's data, contraception usage rates across the country $\% 70$, and modern methods usage rates $49 \%$ in Turkey, $44.4 \%$ in the western black sea region, respectively. ${ }^{17}$ In Konya, the use of any method was $84.9 \%$, and the use of modern method was $71.4 \% .{ }^{11}$ Although the rates are high compared to our study, the limited sample size of this study and the fact that the included study groups were conducted in the city center explain the high rates in Konya. Similarly, in the city center of Canakkale, the rate of method use is $86.3 \%$ and the use of modern methods is $65.7 \%$. ${ }^{13}$ In contrast, in rural areas of Giresun, the use of modern method is reported by $58.8 \% .^{10}$ These results showed that, the modern method using was higher in Karabuk than the average of Turkey and Western Black sea region. Like our status and contraceptive methods preferences $(\mathrm{p}=0.240)$. Methods of contraception according to the settlements of women were analyzed, the most frequently used method in all regions was IUD, while the second most frequently was withdrawal. However, this difference was not statistically significant $(\mathrm{p}=0.108)$.

study, in Karabuk between 2015 and 2016, the frequency of using the family planning method was found to be $80.3 \%$ and the use of modern method was $48.6 \% .{ }^{12}$ It is observed that there is an increase in family planning method usage and modern method usage in Karabuk over the years. It can be linked the education level of the public and the effectiveness of the health services.

In this study, the most common contraceptive method is IUD with $32.2 \%$. The second one was the withdrawal method $(27.6 \%)$. As in Çanakkale, the most frequently used method is IUD with $32.8 \%$ and condom is in the second place with $24.1 \%$. On the contrary, in Konya, condom is the first place $(42.3 \%)$ and IUD $(17.1 \%)$ on the second place. ${ }^{11}$ In the rural area of Giresun, condom was the most preferred method with $31 \%$ and the use of IUD was found to be at a very low level as $3.7 \% .{ }^{10}$ According to the TDHS 2013 data, while the most preferred method was withdrawal $(25.5 \%)$, the most frequently used modern methods were IUD $(16.8 \%)$ and condom was in the second place (15.8\%). ${ }^{6}$ In TDHS 2018 data, while the most preferred method was withdrawal $(20 \%)$, the most frequently used modern methods was condom (19\%) and RIA was in the second place (14\%). ${ }^{17}$ Turkey between 2013 and 2018, it appears that the most preferred method is the same as withdrawal. On the contrary, the most frequently used modern method, IUD, has been replaced by a condom. In Elazig, where have higher birth rates, shows similarities to TDHS 2013 data. In Elazig, the most used method in all age groups is the withdrawal method, and the 
most used modern method is condom. ${ }^{1}$ In a multicenter study that included women of 18-49 age group, the most used method in all age groups was withdrawal with $26.4 \%$ and secondly IUD with $25.8 \%{ }^{14}$ In 2013, In the Western Black Sea Region, the most commonly used method was withdrawal $(30 \%)$, followed by condom $(17 \%)$, IUD (13\%), and tubal ligation (13\%). ${ }^{6}$ In 2018 , the most commonly used method was withdrawal (31\%), followed by condom $(17.1 \%)$, IUD $(9.1 \%)$, and tubal ligation (15.6\%) in the Western Black Sea Region. ${ }^{17}$ While the first two methods of protection in the western black sea region remain similar to withdrawal and condom, a decrease in RIA use and an increase in BTL use are noteworthy. According to the Karacali et al. study in our province, the most frequently used method was found to be withdrawal method (31.0\%). Following this, condom (18.3\%), tubal ligation (16\%), IUD (9.0\%) and OCPs (4.3\%). ${ }^{12}$ In our results, it is significant that the use of RIA is the first among all contraceptive methods. This is since the study is carried out in a tertiary center and professional implementation of the IUD application by staff who require experience. Moreover, According to TNSA 2018 data, while the total fertility rate across was 2.3 children in Turkey. North region was determined the firstly with the lowest fertility rate with 1.6 children. ${ }^{17}$ We attribute the increase in the use of modern methods and the decrease in birth rates, increased awareness, and increased access of women to effective and sustainable contraception methods such as tubal ligation. IUD is a long-acting, easyto-use, high-effective and safe, low-cost, reversible method of protection and is almost as effective as surgical sterilization. Moreover, recent studies have shown an increase in longterm reversible contraceptive method preferences. In USA, this rate was $8 \%$ in 2012 , $14 \%$ in 2014 and $23 \%$ in Uganda. ${ }^{15}$ Nevertheless, there was a significant decrease in sterilization methods. Long-term reversible contraceptive methods are preferred because of the long prevention time, effectiveness, and better child interval. ${ }^{16}$ Furthermore, in parallel with the increase in the education level of patients, the desire to have children at an advanced age and a decrease in the number of children are also effective in the results. ${ }^{15}$

In our study, the most frequently used method between the ages of 15-24 was withdrawal method with $30.9 \%$, and tubal ligation was never used. The most commonly used method in the 25-35 age was IUD (28.2\%) followed by withdrawal $(27.6 \%)$ and the least used method was injectable preparations $(0.1 \%)$. In our study, the use of IUD was the most contraceptive method in the ages higher than 25 .
Similarly, Oztaş at al. found that IUD and BTL using increased in older ages. ${ }^{14}$ Unlike our results, according to TDHS 2013 data, the most preferred is withdrawal method among all age groups. The most common method is condom between the ages of 20-24, and IUD between the ages of 35-39. ${ }^{6}$ In 2018 data, while the most preferred method is withdrawal, secondly was condom in all age. ${ }^{17}$ In Giresun, it was found that as the average age decreased, the use of OCPs and condoms using are increased, and in parallel to this, those who preferred IUD and permanent methods were older than those who used birth control pills and condoms. The most common method aged 18-29 was condom (51.6\%) and the second method was traditional methods $(30.1 \%)$. Between the ages of 30-39, the most common were traditional methods $(33.2 \%)$ followed by condoms with $32.0 \%$. Women between the ages of 40-49 were using the traditional method $(55.5 \%)$ followed by permanent methods with $17.7 \%$ and condoms with $17.3 \% .^{10}$ In Van, traditional methods are preferred more frequently than modern methods in all age groups, and the most preferred modern method is condom. It has been determined that BTL is common over 35 years old, condom between 25-35 years old and IUD under 25 years old. ${ }^{18}$ Variability in birth control method preferences seen in different age groups is also observed among regions and cultures.

In Karabuk, BTL was common between the ages of 36-44. Similarly, according to TDHS 2013 and 2018 data, the rate of BTL increases as the age gets older. ${ }^{6}$ It is $0.2 \%$ between the ages of $20-24,15.1 \%$ at the age of $\geq 35,50-60 \%$ at the age of $\geq 40 .{ }^{6}$ As the age gets older, the increase in irreversible methods is noteworthy. According to TNSA 2018 data, the increase in BTL rates is evident between 2013 and 2018 in the Western black sea region. The reason for this is that women who have reached the desired number of children want to prefer a more permanent method and also BTL is performed daily with laparoscopic surgeries. ${ }^{17}$

We found no relationship between educational status, patients' locations, and contraceptive preferences. While some studies claimed that modern methods are used at higher educational level traditional methods are preferred at the low educational levels. ${ }^{1-10} \mathrm{We}$ think that the reason for the use of IUD in our region at all educational levels is due to our population's desire to have fewer children and to prefer long-acting contraceptive methods. Additionally, the easy access to health institutions and the successful implementation of 
the IUD application by health personnel can be considered as a reason for preference.

In this study, according to the general data of Turkey, it has been observed that the use of any contraceptive method and modern methods is high. Women mostly preferred IUD, which is a long-acting reversible birth control method. The fertility rate was found to be quite low compared to the country in general, and considering this result, we believe that contraceptive methods are used effectively and on time. By increasing fertility policies and accessibility to the health system implemented in our region, unwanted pregnancies will be prevented.

Primary health care centers have an important role in family planning. Long-term and successful family planning can be provided by offering personalized birth control methods in family centers.

\section{REFERENCES}

1. Dogru HY, Oktay G, İşgüder ÇK, Özsoy AZ, Çakmak B, Delibaş İB ve ark. Yaş gruplarına göre kadınların aile planlamasına bakışları ve seçtikleri yöntemlerin değerlendirilmesi: Tersiyer tek merkez deneyimi. Dicle Tip Dergisi 2016; 43(3): 413-8.

2. Audu BM, Yahya SJ, Bassi A. Knowledge, attitude and practice of natural family planning methods in a population with poor utilisation of modern contraceptives. J ObstetGynaecol 2006; 26 : 555-60.

3. Giray H, Keskinoğlu P. The use of effective family planning methods by married women aged 15-49 who have applied to Işıkkent health care center and influencing factors. STED 2006; 15: 236.

4. Kaunitz AM, Hughes JM, Grimes DA, Smith JC, Rochat RW, Kafrissen ME. Causes of maternal mortality in the United States. Obstetrics and gynecology 1985; 65(5): 605-12.

5. Büyükkayacı DN, Yılmazel G. Dogum sonrası ev ziyaretleri yoluyla verilen aile planlaması danısmanlıgının etkili aile planlaması yöntemi kullanımına etkisi. Hemşirelikte Eğitim ve Araştırma Dergisi 2014; 11: 52-8.

6. Türkyılmaz A.S. Türkiye Nüfus ve Sağlık Araştırması 2013, Hacettepe Üniversitesi Nüfus Etütleri Enstitüsü Ankara. http://www.hips. hacettepe.edu.tr/tnsa2013/rapor/TNSA 2013 ana rapor.pdf p.76-87 (13.07.2020)

7. Cakıroglu Y, Yucesoy İ. Kontrasepsiyon ve Aile Planlaması. In: Çiçek MN, Akyürek C, Çelik Ç, Haberal A, Kadın Hastalıkları ve Doğum Bilgisi. 3. basım. Atlas Kitabevi, Ankara; 2012; 933-48.

8. Antić L, Djikanović B, Vuković D. Family planning among women in urban and rural areas in Serbia. SrpArhCelokLek2013; 141(11-12):794-9.

9. Irani L, Speizer I, Barrington C. Attitudes, beliefs and norms relating to contraceptive use among young migrant and non-migrant adults in urban Dar es Salaam, Tanzania. Glob Public Health 2013; 8(9):1048-62

10. Çalışkan BG, Doğan B, Olçum GG. Kırsal bölgede yaşayan kadınların aile planlaması yöntem itercihlerine yaş ve eğitimin etkisi. Türkiye Aile Hekimliği Dergisi 2014; 18(4):189-194.

11. Ruhuşen K, Sayın S, Uçar M, Aslan R, Demirbaş O. Kadınların sosyodemografik özelliklerine göre kontraseptif yöntem kullanma durumları ve bu yöntemleri tercih nedenleri. Türk Aile Hek Derg 2014; 18:134-41.

12. Karaçalı M, Özdemir R. Karabük ilinde 15-49 yaş grubu evli kadınların aile planlaması hizmetlerine erişimini etkileyen faktörler. Türkiye Halk Sağlı̆̆ı Dergisi 2018; 16(2): 131-145.

13. Tanriverdi G, Özkan G, Şenveli S. Çanakkale'deki kadınların aile planlaması yöntemlerini tercih nedenleri. Firat Tip Dergisi 2008; 13(4): 251-254.

14. Öztaş Ö, Artantaş A.B, Tetik B.K, Yalçıntaş, A, Üstü Y, Uğurlu M. Knowledge, attitude and behaviour of married women of 18-49 age group about reproductive health and contraception. Ankara Med J 2015; 15:67-76.

15. Kavanaugh ML, Jerman J. Contraceptive method use in the United States: trends and characteristics between 2008, 2012 and 2014. Contraception 2018; 97(1): 14-21.

16. Tibaijuka L, Odongo R, Welikhe E, Mukisa W, Kugonza L, Busingye I et. al. Factors influencing use of long-acting versus short-acting contraceptive methods among reproductive-age women in a resource-limited setting. BMC women's health 2017; 17(1): 25.

17. Hacettepe Üniversitesi Nüfus Etütleri Enstitüsü. Türkiye Nüfus ve Sağlık Araştırması. 2018: Ankara, Türkiye.

18. Yılmaz A, Tanrıverdi MH, Gücük S, Akan Z. Van il merkezinde evlenme başvurusunda bulunan çiftlerin kontrasepsiyon bilgi durumları. Dicle Tıp Dergisi 2016; 40(3):453-57.

19. Oltuluoğlu H, Başer M. Malatya il merkezinde yaşayan evli kadınların kullandıkları aile planlaması yöntemleri ve seçme nedenlerinin incelenmesi. İnönü Üniversitesi Tıp FakültesiDergisi 2012; 19: 167-74. 